\title{
口回 两 \\ Is behind armour blunt trauma a real threat to users of body armour? A systematic review
} $\square$ 吸

Editor's choice can to access mo
free content

${ }^{1}$ Impact and Armour Group, Department of Engineering and Applied Science, Cranfield Defence and Security, Cranfield University, Defence Academy of the United Kingdom, Shrivenham, Wiltshire, UK ${ }^{2}$ Home Office Centre for Applied Science and Technology, St Albans, Hertfordshire, UK

\section{Correspondence to} Dr D J Carr, Impact and Armour Group, Department of Engineering and Applied Science, Cranfield Defence and Security, Cranfield University, Defence Academy of the United Kingdom, Shrivenham, Wiltshire, UK

d.j.carr@cranfield.ac.uk

Received 2 August 2013 Accepted 14 October 2013 Published Online First 13 November 2013

\author{
Debra J Carr, ${ }_{1}^{1}$ I Horsfall, ${ }^{1}$ C Malbon $^{2}$
}

\section{ABSTRACT}

Introduction Behind armour blunt trauma (BABT) has been defined as a non-penetrating injury caused by the rapid deformation of body armour. There has been an increasing awareness of BABT as an injury mechanism in both the military and civilian worlds; whether BABT results in serious injuries is debatable.

Method A systematic review of the openly accessible literature was conducted using the Preferred Reporting Items for Systematic Reviews and Meta-Analyses method to investigate those injuries classified as BABT and their severity.

Results 50 sources were identified that included pertinent information relevant to this systematic review on BABT injuries. Typical injuries reported included skin contusion, laceration and penetration, rib fracture and contusions to lungs, kidneys, spleen and (rarely) the heart. No evidence of fatal injuries due to BABT was identified. Conclusions Whether BABT can lead to life-threatening injuries when small-arms ammunition impacts body armour components designed to stop that ammunition is debatable. It should be emphasised that other data may be available in government reports that are not openly available. Further research should be considered that investigates developments in body armour, including initiatives that involve reducing burden, and how they affect BABT.

\section{INTRODUCTION}

In the modern military context, the term personal armour includes body armour (waistcoat or vestlike garments covering the torso), helmets (covering the cranium), face and eye protection (primarily visors, glasses, goggles), explosive ordnance disposal suits, and ballistic shields. ${ }^{1}$ More recently, pelvic, neck and extremity protection had been discussed and/or developed..$^{2-4}$ Military body armour provides protection from fragmentation and highvelocity (rifle) bullets; sharp weapons and low-velocity (handgun) bullets are not considered a threat to military personnel. Body armour generally consists of two elements, namely, layers of fabric (woven, non-crimp, felted) and plates (ceramiccomposite, composite). ${ }^{5}$ The fabric component of body armour provides protection from a wide range of threats including, but not limited to, fragmentation, low-velocity (handgun) bullets and stab and slash injuries as chain-mail and metallic plates may be incorporated. ${ }^{5}$ Plates are used to provide protection from high-velocity (rifle) threats.

When body armour is impacted by a projectile, deformation occurs on the rear face and can lead to injury. This deformation is described in the literature using physical size (depth, 'diameter', volume) and/or dynamic properties such as velocity

\section{Key messages}

- Non-perforating impacts on body armour can result in a behind armour blunt trauma (BABT) injury.

- Body armour standards typically describe the measurement of back-face signature (BFS) in 'clay'; BFS does not equate to a severity of BABT injury in humans.

- There is no evidence of life-threatening BABT injuries caused to people impacted against body armour designed to defeat the projectile in question.

and acceleration. A commonly used measure in body armour standard test methods is to record the depth of the permanent indentation formed in a block of Roma Plastilina no. 1 (a clay-like material), or similar material, when a non-perforating bullet strikes body armour mounted in front of it. The depth of the deformation is known as the back-face signature (BFS). However, the BFS does not correlate to specific behind armour blunt trauma (BABT) injuries in humans. ${ }^{6}$ Other agencies, particularly those concerned with non-perforating impacts onto plates, use alternative representations of the human thorax.

BABT has been defined as non-penetrating injuries caused by the rapid deformation of body armour. ${ }^{7}$ More recently, a definition for injuries occurring when body armour is impacted, but not perforated, has been suggested that separates injuries that include skin laceration from those that are restricted to skin contusion and rib damage. ${ }^{8}$ Generally, BABT is considered to be a type of blunt trauma injury; other injury mechanisms included in the same broad grouping are road traffic accidents and crush injuries. ${ }^{7-11}$ However, BABT occurs over a shorter period of time, due to an impact event by a faster projectile. During the impact event, the body armour and underlying tissues accelerate and deformation occurs. Stress waves are generated and propagate through the body armour and the underlying tissues (including those not in direct contact with the armour); they may be transmitted and/or reflected by the armour components and/or various tissues depending on the speed of sound in the material. ${ }^{11-14}$ The applied shear stresses may result in tearing of tissue. ${ }^{75-17}$ It is generally accepted that the gross deformation of the chest and the duration and rate at which this deformation occurs affect the injuries observed. ${ }^{714} 17$ However, it is worth noting that the majority of studies 
reported in the literature that investigate the formation of such stress waves consider hard plates rather than soft armour.

There has been an increasing awareness of BABT as an injury mechanism in both the military and civilian worlds; however, whether BABT results in serious injuries is debatable. $71517-20$ This work aimed to systematically review the literature regarding the risk of a life-threatening BABT injury occurring behind body armour.

\section{METHOD}

A systematic review of the open literature was conducted using the Preferred Reporting Items for Systematic Reviews and Meta-Analyses (PRISMA) method. Sources of peer-reviewed information from databases were identified using Web of Knowledge, Science Direct, Google Scholar and the Ballistics Injury Archive, which provides a database for military research purposes for Service and H.M. Government Officers and Research Establishments. US Government reports were identified using the Defense Technical Information Center, an online depository of Department of Defense and government funded research. The Barrington Digital Library, Cranfield University's Library at The Defence Academy of the UK, was also searched particularly for MSc and PhD theses of interest. A full set of the Personal Armour Systems Symposium (PASS) proceedings was hand-searched. PASS was started in 1990 as the Ballistic Testing of Personal Armour Symposium (BTPA) at the former Stores and Clothing Research and Development Establishment in Colchester. In this PRISMA review, proceedings from BTPA1990 to PASS 2012 inclusive were consulted.

Keywords used for these searches were 'body armour', 'behind armour blunt trauma', 'BABT', 'female', 'injur"' and 'fatalit"'. Reference lists from the articles, reports, theses and conference papers identified were hand-searched to identify additional resources. Only primary sources were used in the literature review.

\section{RESULTS}

Fifty sources included pertinent information relevant to this systematic review on BABT injuries; no other systematic reviews on the subject were identified. The PRISMA flow chart is given in Figure 1. Specifically, 21 conference papers, ${ }^{3} 11-1321-3512$ journals articles, 247810151718 36-39 six reports, $9141640-42$ five articles on websites, ${ }^{20} 43-46$ three $\mathrm{PhD}$ theses, ${ }^{47-49}$ one standard test method $^{6}$ and two books ${ }^{50}$ were identified. Data obtained were divided into the following topics: injury mechanisms, wounded personnel, killed personnel and female injuries.

\begin{tabular}{|c|c|c|c|c|c|}
\hline & \multicolumn{3}{|c|}{ Open access } & \multicolumn{2}{|c|}{ Limited access } \\
\hline Source & Databases & Inter & & Barrin & on Library \\
\hline Identification & 12 & 12 & & & 26 \\
\hline Screening & & $\begin{array}{r}\text { Pertin } \\
50\end{array}$ & & & \\
\hline Variable & $\begin{array}{c}\text { Injury } \\
\text { mechanisms } \\
23\end{array}$ & $\begin{array}{c}\text { Wounded } \\
13\end{array}$ & $\begin{array}{c}\text { Killed } \\
3 \\
3\end{array}$ & $\begin{array}{c}\text { Female } \\
2\end{array}$ & $\begin{array}{c}\text { Supporting } \\
9\end{array}$ \\
\hline
\end{tabular}

Figure 1 Results of Preferred Reporting Items for Systematic Reviews and Meta-Analyses (PRISMA) review.
Injury mechanisms

In work published in 1990, a single 'typical' pressure-time history is reported during BABT experiments which consisted of two peaks: a peak pressure of $\sim 1750$ mbar occurred at $\sim 0.5 \mathrm{~ms}$ after the impact event, which was followed by a peak of $\sim 900$ mbar at $\sim 3 \mathrm{~ms}^{32}$ This response is very similar to that reported by later researchers. ${ }^{12} 222531$ These later researchers used high speed imaging of impacts onto gelatine, pressure sensors mounted in gelatine, and accelerometers mounted on ribs of, and pressure sensors in, anaesthetised pigs to record the stress waves. ${ }^{12} 26{ }^{31}$ It is broadly accepted that the short duration first peak is related to the initial impact event onto the body armour; the second and later peak is related to the macroscopic deformation of the armour into the body. ${ }^{173132}$ Both peaks, but particularly the first, are affected by armour construction. ${ }^{25} 3237$

Pencilling is considered to be a particular type of BABT and has been defined as '... a deformation characteristic of body armour, which is only associated with the evolution of lightweight and flexible armours' and '... comparable to an entry wound from a ballistic injury'. ${ }^{27} 29$ A narrow, tapered, deep deformation of the soft body armour into the torso occurs. Pencilling was observed, but not described as such, by several organisations during the mid-1990s when Dyneema Fraglight was assessed as a possible future fabric for use in military body armour.

\section{Wounded personnel}

Injuries to two police officers wearing a seven layer soft armour design to provide protection from 0.38 calibre ammunition has been described. ${ }^{9} 15$ Field trials of such body armour comprising of seven-layers of Kevlar 29 began in the USA in December 1975. In both of the recorded incidents, police officers were struck on the thorax at close range by 0.38 calibre bullets. Both officers were able to chase their assailants, having suffered only contusion and minor lacerations to the chest; in the first case, the officer was struck twice (contusion sizes $30 \mathrm{~mm} \times 40 \mathrm{~mm}$, $50 \mathrm{~mm} \times 60 \mathrm{~mm} ; 20 \mathrm{~mm} \times 30 \mathrm{~mm}$ ). Neither officer suffered rib, cardiac or pulmonary damage and were discharged from hospital after 3 and 2 days, respectively.

Injuries sustained to two police officers (one female officer) shot wearing soft body armour have been described. ${ }^{8}$ The armours were not perforated. The female officer was impacted with ammunition from her own weapon $(9 \mathrm{~mm}$; no further details given) and suffered a $30 \mathrm{~mm}$ diameter open wound that was $15 \mathrm{~mm}$ deep; as well as skin contusion, a fractured rib and lung contusion. In the case of the male officer, also shot with $9 \mathrm{~mm}$ ammunition, two lacerations $\sim 38 \mathrm{~mm}$ deep and associated contusions and abrasions were described. Other examples of similar incidents when police officers have survived low-velocity (handgun) non-perforating bullet impacts are available in the literature and in the IACP/DuPont Kevlar Survivors' Club database.

Of 58 US military personnel (91 injuries) wounded in action in Somalia between 3 and 4 October 1993, four suffered blunt injuries to the thorax (including back) and one to the abdomen. ${ }^{38}$ The authors comment on two incidents of interest to this review: '... individual was hit in the flank by an AK-47 bullet that first struck a wall he was standing near. His only injury was a severe flank hematoma that eventually extended around to his groin a few days later. His urine tested negative for blood, and he was returned to duty during the battle.' and '...a ranger shot in the center of the armored chest plate. The soldier was knocked over, looked down at his chest, then got to his feet and returned fire. The bullet had hit his chest and ricocheted off his armored plate into his arm, causing only minor soft-tissue injury. ${ }^{38}$ 
Seventeen incidents of BABT suffered by Russian personnel suggested that for impacts from a range of ammunition (primarily $7.62 \mathrm{~mm}$; some $7.71 \mathrm{~mm}$ ), the primary injury suffered was accumulation of blood at the site of contusions; typical size of the ecchymoses was $100 \mathrm{~mm} \times 100 \mathrm{~mm}$ and resulted in 2 weeks hospitalisation. ${ }^{33}$ More serious injuries were reported in two incidents (rupture and abscessing of lung; 1 and 3 months in hospital, respectively). All impact sites were on the thorax, some on the back.

Such injuries resulting from high-velocity (rifle) bullet impacts appear similar to those reported in newspapers and via the internet for military personnel injured in Iraq and Afghanistan. ${ }^{43-46}$

Pencilling has been reported in a case study involving a young man shot while wearing soft body armour: two rounds perforated his body armour and chest; however, a third round did not perforate the armour, but resulted in a wound extending into the subcutaneous fat. ${ }^{29} 47$ Two incidents suffered by US police officers (one female officer) were described as injuries caused by 'deformation punch'. ${ }^{35}$ The incidents resulted in deep, localised penetrating injuries (15 and $38 \mathrm{~mm}$, respectively). The authors noted that both individuals were below average weight (for the two sexes and the overall cohort). It was also suggested that thinner, lighter-weight and less-stiff body armour might contribute towards such injuries.

\section{Killed personnel}

A Vietnam War US Army BABT fatality has been reported. ${ }^{18} \mathrm{~A}$ single M-16 round impacted the area of the third intercostal space on the left side of his body; the bullet perforated the soldier's body armour, but not the pleural cavity. The soldier died and the post-mortem revealed he had suffered extensive pulmonary contusions to the upper and lower lobes. Details of the body armour worn were not provided, but it is likely to have been a M69 flak jacket containing multiple layers of woven nylon 6,6 fabric (6-12 layers depending on specific location in the garment), which was not designed to provide protection from high-velocity (rifle) rounds such as those fired from a $\mathrm{M}-16$. $^{50}$

A second fatal BABT case study was reported in the literature in $1982 .{ }^{39}$ A police officer was shot using a $0.45-70$ rifle; the bullet did not perforate the body armour but the officer died. Injuries included lacerated skin $(41 \mathrm{~mm} \times 39 \mathrm{~mm})$, fractured rib, contusion to the lung and fractured blood vessels adjacent to the heart. A schematic drawing and photograph of the body armour suggested the deformation would have perforated in the body was approximately $100 \mathrm{~mm}$; it appears to be a case of pencilling. The body armour worn by the officer was designed to protect from 0.44 Magnum ammunition and contained 18 layers of Kevlar; thus, it was not designed to protect from the ammunition that killed the officer.

\section{Female injuries}

Work specifically on BABT suffered by female wearers of body armour appears restricted to that conducted by Wilhelm in the USA. $^{35} 49$ A comparison between female and male US police officer BABT injuries suggested that female officers suffer a higher risk of injury. ${ }^{35} 49$ Data were collected from the IACP/ DuPont Survivor's Club and 14 survivors (four women) consented to assist in the study. Based on the injuries sustained, an Abbreviated Injury Score (AIS) was assigned; the four female participants' injuries were rated as AIS 3, 3, 1 and 1, respectively. In comparison, eight male participants were assigned $\mathrm{AIS}=1$, one was assigned $\mathrm{AIS}=2$ and one assigned $\mathrm{AIS}=3$, although the authors acknowledged the small sample size. Higher AIS were associated with open wounds, lung contusions and rib fractures.

\section{DISCUSSION}

Wilson, writing in 1921 about wound ballistics, stated 'Comparatively speaking, it is not the push of the elephant's shoulder with which we are concerned, but rather the kick of the mule. $^{36}$ This quote can equally be applied to BABT. Observations regarding the importance of rate of deformation as well as deformation physical size have been recognised from the earliest 'modern' research into BABT. ${ }^{16}{ }^{40-42}$ What is clear is that body armour tested against recognised standards saves lives; of course, the projectile does not perforate the body armour during this testing or it would fail. This review has found no evidence in the academic literature for fatalities due to BABT when personnel are attacked by a threat for which the body armour they were wearing was designed.

Although criticism of the use of a BFS measurement in body armour standard test methods has been widely discussed for over 35 years, various authors have commented on the lack of evidence for fatalities occurring from BABT for personnel wearing body armour. ${ }^{24} 283034$ This may, of course, be due to the fact that the soft body armour worn was designed and tested against a specific BFS requirement. Any body armour designer knows that typical hand-gun ammunition can often be stopped by a body armour pack with fewer layers than required to pass a BFS limit as well as a non-perforation result. If such thinner body armour packs were used or packs containing fabric of poorer performance, then BABT may become a more serious injury/fatality mechanism. With respect to hard armour (plates), the chair of the NATO specialist team on body armour reported in 1996 that there was no evidence for significant BABT with respect to armour providing protection for equivalent energy levels of that of $5.56 \mathrm{~mm}$ rounds and insufficient evidence to comment for energy levels equivalent to those between 5.56 and $12.7 \mathrm{~mm}$ ammunition. ${ }^{28}$ In 2002, the team concluded in its final report: 'From experience on the combat field there is very little evidence of its existence, apart from ... minor breathlessness or bruising. ${ }^{21}$

\section{CONCLUSIONS}

Body armour design continues to be optimised resulting in thinner, lighter and more compliant armours, all of which the user desires. However, an enhanced risk due to BABT might emerge as this process continues if armour was only designed to provide protection from a specified ballistic threat; in this respect, the inclusion of a BFS measurement in test standards provides a further measure of quality assurance to the procurer and user. Wearers might suffer a relatively minor injury due to a non-perforating impact onto body armour, for example, haematoma, minor laceration and cracked ribs. However, it should be emphasised that other data may be available in government reports that are not openly available. Further research should be considered that investigates developments in body armour, including initiatives that involve reducing burden, and how they affect BABT.

Acknowledgements The authors acknowledge the assistance of Mr Payne (BIA).

Contributors CM planned and commissioned the literature review. DJC conducted the review overseen by $\mathrm{IH}$. All authors contributed to the writing of this paper and approved the content of this manuscript.

Funding This work was funded by Home Office Centre for Applied Science and Technology (Tasking number HOS/11/050). 
Competing interests None.

Ethics approval No ethical approval was required to complete this research.

Provenance and peer review Not commissioned; externally peer reviewed.

\section{REFERENCES}

1 UK Ministry of Defence. Proof of ordnance, munitions, armour and explosives: Part 2-guidance, defence standard 05-101 part 2 issue 1. Glasgow, UK: Defence Procurement Agency, 2005.

2 Sakaguchi SM, Carr DJ, Horsfall I, E G. Protecting the extremities of military personnel: fragment protective performance of one- and two-layer ensembles. Textile Res J 2012;82:1295-303.

3 Helliker M, Carr DJ, Lankester C, et al. Effect of laundering on the fragment protective performance of single jersey knit silk used in personal protection. Personal Armour Systems Symposium 2012 (PASS2012); 2012 17-21 September; Hotel Pyramide, Nuremburg, Germany.

4 Lewis EA, Pigott MA, Randall A, et al. The development and introduction of ballistic protection of the external genitalia and perineum. J Royal Army Med Corps 2013;159(Suppl 1):i15-17.

5 Tobin L, Iremonger M. Modern body armour and helmets: An introduction. Canberra, Australia: Argros Press, 2006

6 U.S Department of Justice. Ballistic resistance of body armor nij standard-0101.06. Washington, DC: U.S. Department of Justice, 2008.

7 Cannon L. Behind armour blunt trauma—an emerging problem. J Royal Army Med Corps 2001;147:87-96.

8 Wilhelm M, Bir C. Injuries to law enforcement officers: the backface signature injury. Forensic Sci Int 2008:174:6-11.

9 Soderstrom CA, Carroll AW, Hawkins CE. Technical report eb-tr-77057. The medical assessment of a new soft body armor. Chemical Systems Laboratory, Aberdeen Proving Ground Maryland: Department of the Army, 1978.

$10 \mathrm{O}^{\prime}$ Connell KJ, Frazier HA, Clark MA, et al. The shielding capacity of the standard military flak jacket against ballistic injury to the kidney. J Forensic Sci 1988:33:410-7.

11 Proud WG, Goldrein HT, Esmail S, et al. A review of wound ballistics literature: the human body and injury processes. In: Leixeira-Dias F, Dodd B, Torres Marques A, Lach L, Walley S, eds. Security and use of innovative technologies against terrorism LWAG light-weight armour for defence \& security; 18-19 May 2009. Aveiro, Portugal, Universidade de Aveiro, 2009:65-82.

12 van Bree JLMJ, van der Heiden N. Behind armour blunt trauma analysis of compression waves. In: Gotts PL, Kelly PM, eds. Personal armour systems symposium 1998 (PASS98). Colchester, UK: Defence Clothing and Textiles Agency, Science and Technology Division, UK MoD, 1998:433-40.

13 Cannon L, Tam W. The development of a physical model of non-penetrating ballistic injury. In: Crewther IR, ed. 19th International Symposium of Ballistics; 7-11 May; Interlaken, Switzerland, 2001.

14 Stuhmiller JH, Shen WS, Niu E. Modeling for military operational medicine scientific and technical objectives. San Diego, CA: Jaycor, 2003.

15 Carroll AW, Soderstrom CA. A new nonpenetrating ballistic injury. Ann Surg 1978;188:753-7.

16 Goldfarb MA, Ciure TF, Weinstein MA, et al. Technical report eb-tr-74073. A method for soft body armor evaluation: medical assessment. Edgewood Arsenal, Aberdeen Proving Ground Maryland: Department of the Army, 1975.

17 Prat N, Rongieras F, Sarron J-C, et al. Contemporary body armor: Technical data, injuries, and limits. European Journal of Trauma and Emergency Surgery 2012;38:95-105.

18 Shephard GH, Ferguson JL, Foster JH. Pulmonary contusion. Ann Thorac Surg 1969;7:110-19.

19 Galbraith KA. Combat casualties in the first decade of the 21st century-new and emerging weapon systems. J Royal Army Med Corps 2001;147:7-14.

20 McBride R. lacp/dupont kevlar survivors' club. 2012.

21 Anderson IB, Knudsen PJT, Sarron J-C, et al. A review of the work of the task group on behind armour blunt trauma. In: van Bree JLMJ, ed. Personal Armour Systems Symposium 2002 (PASS2002). The Hague, The Netherlands: TNO Prins Maurits Laboratory, 2002:353-9.

22 Crucq LWB. Predicting incapacitation and survival probabilities of non-penetrating impacts against hard/soft body armour. In: Gotts PL, Kelly PM, eds. Personal armour systems symposium 1998 (PASS98). Colchester, UK: Defence Clothing and Textiles Agency, Science and Technology Division, UK MoD, 1998.

23 Drapela $\mathrm{P}$, Lorenzo $\mathrm{R}$, Lampert $\mathrm{S}$. How to quantify the effects of non-lethal kinetic weapons. In: Bless S, Walker J, eds. 24th International Symposium on Ballistics; 23-27 September; New Orleans, LA, 2008.

24 Brown E. Home office ballistic standards. In: Tobin LB, ed. The Ballistic Testing of Personal Armour (BTPA). Colchester, UK: Stores and Clothing Research and Development Establishment, UK MoD, 1990:127-42.

25 van Bree JLMJ, Fairlie G. Compression wave experimental and numerical studies in gelatine behind armour. In: Reinecke WG, edr. 18th International Symposium on Ballistics; 15-19 November; San Antonio, Texas: CRC Press; 1999.
26 van Bree JLMJ, van der Heiden N. Behind armour pressure profiles in tissue simulant. In: Gotts PL, Kelly PM, ed. Personal Armour Systems Symposium 1996 (PASS96), Colchester, UK: Defence Clothing and Textiles Agency, Science and Technology Division, UK MoD; 1996.

27 Lewis EA, Watson $\mathrm{CH}$, Horsfall I. Behind armour blunt trauma effects after low-velocity ballistic impact. In: Burman N, Anderson J, Katselis G, eds. 21st International Symposium on Ballistics; Adelaide, Australia: Defence Science and Technology Organisation with the cooperation of the International Ballistics Committee, 2004.

28 Knudsen PJT. The nato specialist team on body armour. In: Gotts PL, Kelly PM, eds. Personal Armour Systems Symposium 1996 (PASS96). Colchester, UK: Defence Clothing and Textiles Agency, Science and Technology Division, UK MoD, 1996:211-7.

29 Lewis EA, Johnson P, Bleetman A, et al. An investigation to confirm the existance of 'pencilling' as a non-penetrating behind armour injury. In: van Bree JLMJ, edr. Personal Armour Systems Symposium 2004 (PASS2004). The Hague, The Netherlands: TNO Prins Maurits Laboratory, 2004:151-60.

30 Frank DE. Police personal body armor. What do we know? What do we need to know? What would we like to know? In: Gotts PL, Kelly PM, eds. Personal Armour Systems Symposium 1994 (PASS94). Colchester, UK: Defence Clothing and Textiles Agency, Science and Technology Division, UK MoD, 1994:343-51.

31 Gotts PL, van Bree JLMJ. The 'twin peaks' of babt. In: Gotts PL, Kelly PM, eds. Personal Armour Systems Symposium 2000 (PASS2000). Colchester, UK: Defence Clothing and Textiles Agency, Science and Technology Division, UK MoD, 2000:371-9.

32 Iremonger MJ, Bell SJ. Simulation of behind-armour trauma. In: Tobin LB, edr. The Ballistic Testing of Personal Armour (BTPA). Colchester, UK: Stores and Clothing Research and Development Establishment, UK MoD, 1990:191-202.

33 Mirzeabasov TA, Belov DO, Tyurin MV, et al. Further investigation of modelling system for bullet-proof vests. In: Gotts PL, Kelly PM, eds. Personal armour systems symposium 2000 (PASS2000). Colchester, UK: Defence Clothing and Textiles Agency, Science and Technology Division, UK MoD, 2000:211-33.

34 Miner LH. Testing of bullet resistant vests made from para-aramid fabrics to nij std-0101.03 and ppaa std-1989-05. In: Tobin LB, edr. The Ballistic Testing of Personal Armour (BTPA). Colchester, UK: Stores and Clothing Research and Development Establishment, UK MoD, 1990:69-112.

35 Bir CA, Wilhelm M. Female body armor assessment: Current methods and future techniques. In: van Bree JLMJ, ed. Personal armour systems symposium 2004 (PASS2004). The Hague, The Netherlands: TNO Prins Maurits Laboratory, 2004:139-50.

36 Wilson LB. Dispersion of bullet energy in relation to wound effects. Mil Surg 1921; XLIX:241-51.

37 Shen W, Niu Y, Bykanova L, et al. Characterizing the interaction among bullet, body armor, and human and surrogate targets. J Biomech Eng 2010;132:1-11.

38 Mabry RL, Holcomb JB, Baker AM, et al. United states army rangers in somalia: an analysis of combat casualties on an urban battlefield. J Trauma Inj Infect Crit Care 2000;49:515-29

39 Thomas GE. Fatal .45-70 rifle wounding of a policeman wearing a bulletproof vest. J Forensic Sci 1982;27:445-9.

40 Prather RN, Swann CL, Hawkins CE. Technical report eb-tr-77055. Backface signatures of soft body armors and the associated trauma effects. Chemical Systems Laboratory, Aberdeen Proving Ground Maryland: Department of the Army, 1977.

41 Montanarelli N, Hawkins CE, Goldfarb MA, et al. Technical report Iwl-tr-30b73. Protective garments for public officials. US Army Land Warefare Laboratory, Aberdeen Proving Ground Maryland: Department of the Army, 1973.

42 Metker L-RW, Prather RN, Johnson EM. Technical report eb-tr-75029. A method for determining backface signatures soft body armor. Edgewood Arsenal, Aberdeen Proving Ground Maryland: Department of the Army, 1975.

43 Weaver T. Soldier survives sniper's bullet after stopping to eat. Stars and Stripes, 2005. http://www.stripes.com/news/reporter-s-notebook-soldier-survives-sniper-sbullet-after-stopping-to-eat-1.34885

44 Ministry of Defence. Body armour saves soldier's life in afghanistan. Ministry of Defence; 2010. http://www.mod.uk/Defencelnternet/DefenceNews/Military Operations/BodyArmourSavesSoldiersLifelnAfghanistan.htm (accessed 19 Feb 2012).

45 Ministry of Defence. Body armour saves uk soldiers in helmand fire fight. Ministry of Defence, 2011. http://www.mod.uk/Defencelnternet/DefenceNews/ MilitaryOperations/BodyArmourSavesUkSoldiersInHelmandFireFight.htm (accessed 19 Feb 2012)

46 Firth N. British soldier had sniper's bullet pulled from his back by comrade after being shot by taliban. Mail online, 2009. http://www.dailymail.co.uk/news/article1191872/Soldier-snipers-bullet-pulled-comrade-shot-Taliban.html (accessed 19 Feb 2012).

47 Lewis EA. Pencilling: a novel behind armour blunt trauma injury [Unpublished PhD thesis]. Cranfield University, 2005.

48 Bir CA. The evaluation of blunt ballistic impacts of the thorax [ Unpublished PhD thesis]. Wayne State University, 2000.

49 Wilhelm MR. A biomechanical assessment of female body armor [Unpublished PhD thesis]. Wayne State University, 2003.

50 Dunstan S. Flak jackets 20th century military body armour. London: Osprey Publishing, 1984. 